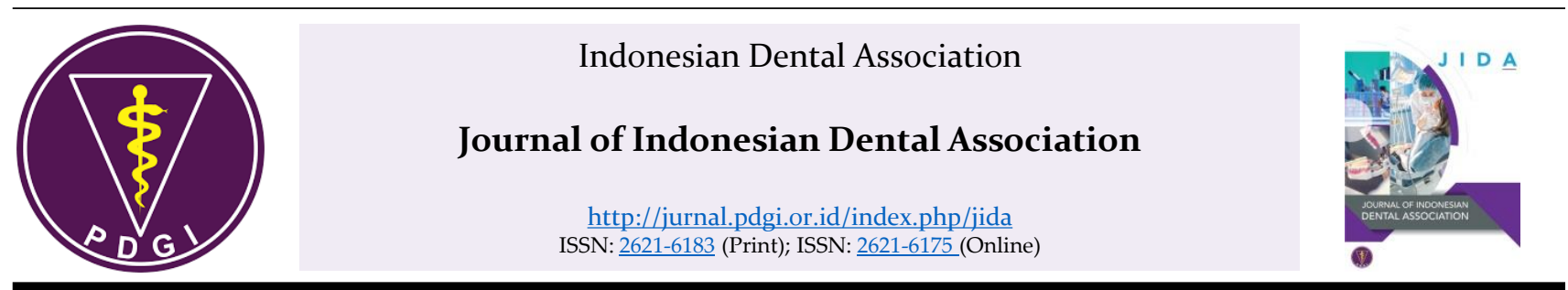

Research Article

\title{
The Effectivity of Tamarillo (Cyphomandra betacea Sendtn.) Decoction Against The Growth of Candida albicans
}

\author{
Putu Chintya Nitiyani Santika ${ }^{1}$, Janti Sudiono ${ }^{2 \S}$ \\ ${ }^{1}$ Undergraduate Student, Faculty of Dentistry, Trisakti University, Indonesia \\ ${ }^{2}$ Department of Oral Pathology, Faculty of Dentistry, Trisakti University, Indonesia
}

Received date: August 30, 2019. Accepted date: January 14, 2020. Published date: February 20, 2020.

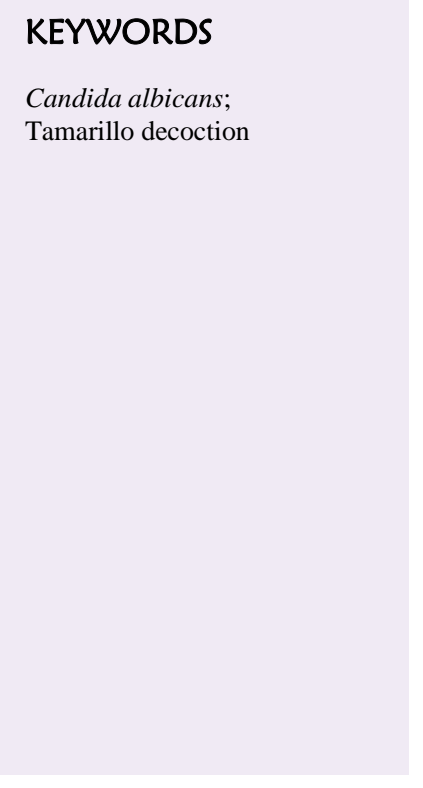

\begin{abstract}
Introduction: Candida albicans is an opportunistic fungus that can become a pathogen which causes candidiasis when the condition of the oral cavity is imbalanced. Tamarillo (Cyphomandra betacea Sendtn.) is a low-fat and low-calorie fruit that has high nutritional value and provides a number of micronutrients, including vitamins, minerals, and chemical compounds, such as flavonoids, terpenoids, steroids, saponins, alkaloids, and tannins. The pharmacological effects of flavonoids, tannins, and saponins are antimicrobial and anti-fungal. Objective: This study was conducted to determine the effectiveness of a tamarillo (Cyphomandra betacea Sendtn.) decoction against the growth of Candida albicans. Method: The concentrations of tamarillo decoction used in this study were $6.25,12.5,25,50$, and $100 \%$. This experimental laboratory study used the well diffusion method by measuring the diameter of the inhibitory zone. Nystatin and distilled water were used as the positive and negative controls, respectively. Results: Result showed that Tamarillo has antibacterial effect against Candida albicans. The decoction of 50\% tamarillo was found to be the minimum inhibitory concentration on Candida albicans. Conclusion: Starting at a 50\% concentration, tamarillo decoction is an effective growth inhibitor of Candida albicans. Hence, this natural product might be applied as an adjunctive therapy for oral candidiasis. However, further studied are still needed to confirm this result.
\end{abstract}

\footnotetext{
${ }^{5}$ Corresponding Author

E-mail address: jantish@hotmail.com (Sudiono J)
} 


\section{INTRODUCTION}

Candida infections are often found in the Indonesian population whereas one of these commonly found infections is oral candidiasis. ${ }^{1}$ In Indonesia, oral candidiasis account for $50-60 \%$ of candidiasis found in the human. ${ }^{2}$ Candidiasis occurs throughout the world, infecting males and females of every age, although it affects females more often (70\%) than males. ${ }^{3}$ Candida albicans is part of the normal flora of oral, digestive, and vaginal mucosa. ${ }^{4}$ However, it is an opportunistic species that can become a pathogen if the ecosystem within the oral cavity is imbalanced. ${ }^{5}$ This imbalance occurs if the immune system is suppressed; if the skin has constant humidity from sweat, water, urine, or saliva; or if oral consumption of antibiotics is routine. ${ }^{6}$

Candida infection requires anti-fungal therapy. However, the use of anti-fungal therapy may cause fungal resistance and other side effects such as rash, abdominal pain, diarrhea, indigestion, headache. ${ }^{7}$ Traditional therapy for Candida infection has been started recommended for use more recently in developing countries, including Indonesia. This traditional or herbal therapy has been used as a public choice due to minimal side effects and decreased risk of resistance, has the capability to replace synthetic drugs. ${ }^{8}$ The potency of herbal therapy has often been proved empirically. Diseases that are not curable by medical therapies may be cured by herbal therapy. ${ }^{9}$ Traditional or herbal therapy uses based material derived from plant and natural substances. Herbal therapy has continued to be popular among population because the material of this therapy are easily found. ${ }^{10}$ One such example of herbal therapy is that which uses tamarillo (Cyphomandra betacea Sendtn.), more commonly known as the "fruit of Terung Belanda."

In Indonesia, tamarillo is not popular as herbal plant among population, even though it is a local commodity that is easily produced. ${ }^{11}$ Therefore research of the tamarillo fruit is necessary to establish the fruit's potency as herbal medicine. The fruit is low-fat, low-calorie, and high-protein, contains various micronutrients, such as vitamins, minerals, and bioactive components like flavonoids, terpenoids, steroids, saponins, alkaloids, and tannins. ${ }^{12}$ Flavonoids have been revealed to have antimicrobial properties, especially those within the terpenoid flavonoid, flavon, and isoflavon groups. The high potency of flavonoids to delay the growth of pathogen spores of plants is the basis of proposed flavonoid usage to treat fungal human pathogens. ${ }^{13}$

A previous study proved the effectiveness of tamarillo fruit (Solanum betaceum) extract. An effective dose of tamarillo fruit (as much as $200 \mathrm{mg} / \mathrm{kg}$ body weight decreased malondialdehyde $(9.52 \mathrm{nmol} / \mathrm{mL}$ to $6.04 \mathrm{nmol} / \mathrm{mL}$ ) within white male rat (Rattus norvegicus strain wistar) blood contaminated by carbon tetrachloride. ${ }^{14}$ Another study revealed that flavonoids found within a decoction of papaya leaves inhibited the growth of Candida albicans due to their anti-fungal properties. ${ }^{15}$ An additional study revealed that alkaloids, flavonoids, steroids, polyphenols, and tannins found within a mango leaf ethanol extract were active antifungal components. ${ }^{16}$ Extract of Gelinggang leaves (Cassia alata L.) and Rosella flower leaves (Hibiscus sabdariffa Linn) have also been shown to inhibit the growth of Candida albicans. ${ }^{17,18}$ Based on these studies, the present study aimed to determine the effectiveness of a tamarillo (Cyphomandra betacea Sendtn.) fruit decoction against the growth of Candida albicans.

\section{MATERIALS AND METHODS}

The population of this experimental laboratory study was the Candida albicans wild-type strain ATCC 10231 derived from the laboratory culture of the Microbiology Center of Research and Education (MiCORE), Faculty of Dentistry, Trisakti University. One needle was used to obtain one colony from this bank culture of Candida albicans and place it into a broth heart infusion (BHI) solution. It was then incubated for $24 \mathrm{~h}$ at a temperature of $37^{\circ} \mathrm{C}$.

The sample herbal plant used was tamarillo (Cyphomandra betacea Sendtn.) fruit from the collection of Balai Penelitian Tanaman Rempah dan Obat (BALITRO), Bogor. As much as $100 \mathrm{~g}$, or 4 tamarillo fruits, was cut into small pieces and decocted within $1 \mathrm{~L}$ of water at a temperature of $90^{\circ} \mathrm{C}$ for $5 \mathrm{~min}$ to obtain a $50 \mathrm{~mL}$ tamarillo decoction with concentration of $100 \%$. The $100 \%$ concentration of decoction was diluted into concentrations of $50 \%, 25 \%, 12.5 \%$ and $6.25 \%$. Nystatin and aquadest were used as the positive and negative controls, respectively. After Candida albicans was incubated, it was cultured on Sabouraud Dextrose Agar (SDA) media. A hole was made in each SDA culture of Candida albicans, and then the holes were filled with various concentrations of the tamarillo decoction and the positive and negative controls. These mixtures were then incubated at $37^{\circ} \mathrm{C}$ for $24 \mathrm{~h}$. Three repeated samples were used for each concentration. The inhibitory zone was measured in millimeters by a caliper.

\section{Statistical Analysis}

Data was analyzed using One way ANOVA test and Shapiro-Wilk test for normality data test. $p<0.05$ was set for the significant level. Statistical calculations were performed with SPSS Statistics for Windows software version 20 (IBM, USA). 


\section{RESULTS}

The tamarillo fruit used in this study was Cyphomandra betacea Sendtn. This selection was based on the determination test of herbal plant taxonomy at Bogor Institute of Sciences Balitro, Bogor, Indonesia. The phytochemical test of the tamarillo fruit decoction was performed in BALITRO. The results of the test are shown in Table 1.

The inhibitory zone diameters of the different concentrations of the tamarillo fruit decoction, as well as those of the positive and negative controls, are shown in Table 2 and Fig. 1. As seen in Table 2, the means of the inhibitory zone diameter of the $100 \%$ and $50 \%$ concentrations were $8.71 \mathrm{~mm}$ and $8.19 \mathrm{~mm}$, respectively. The data were normally distributed (as shown by the results of the Shapiro-Wilk test; $p>0.05)$. One way ANOVA test also showed a significant difference between concentration of $50 \%$ and $100 \%$ compared to the negative control with $p<0.05$.

Table 1. Phytochemical contents of the tamarillo fruit decoction (Cyphomandra betacea Sendtn.).

\begin{tabular}{lc}
\hline \multicolumn{1}{c}{ Results } \\
\hline Alkaloid & + \\
Saponin & + \\
Tannin & + \\
Phenol & - \\
Flavonoid & + \\
Triterpenoid & + \\
Steroid & - \\
Glycoside & + \\
\hline
\end{tabular}

Table 2. Inhibitory zone diameters of the tamarillo decoction extracts (Cyphomandra betacea Sendtn.) and the positive and negative controls.

\begin{tabular}{ccc}
\hline Concentration $(\%)$ & N & Mean \pm SD \\
\hline Positive control & 4 & $15.05 \pm 0.56$ \\
100 & 4 & $8.71 \pm 0.71$ \\
50 & 4 & $8.19 \pm 0.34$ \\
25 & 4 & - \\
12.5 & 4 & - \\
6.25 & 4 & - \\
Negative control & 4 & \\
\hline
\end{tabular}

\section{DISCUSSION}

This study showed that the inhibitory potential of tamarillo fruit decoction extract against the growth of Candida albicans occurred started at concentrations of

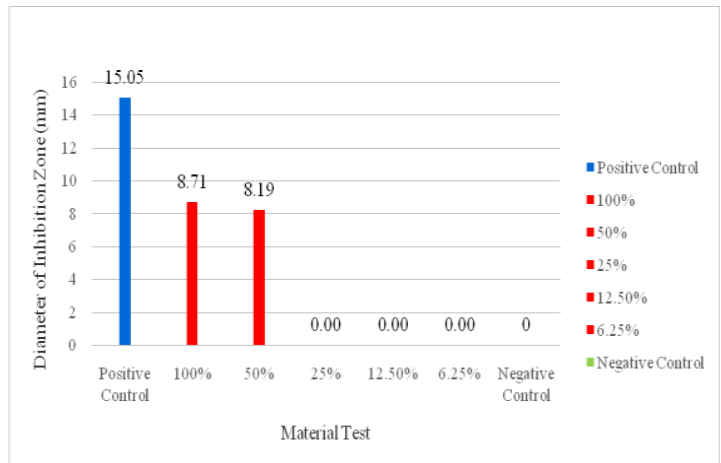

Figure 1. Means of the inhibitory zone diameter of the positive control, tamarillo decoction extract, and negative control.

Candida albicans occurred started at concentrations of $50 \%$. The inhibitory potential is categorized into four grades: low, middle, strong, and quite strong. The grade of inhibitory diameter zones are categorized as $<10 \mathrm{~mm}$, 10-15 mm, 16-20 mm, and > 20mm for low, middle, strong, and quite strong, respectively. ${ }^{17}$ In the present study, among concentration of the tamarillo fruit decoction, the $100 \%$ concentration had the highest inhibitory zone with the inhibitory zone of $(8.71 \pm 0.71 \mathrm{~mm})$. This potency was lower than the positive control of nystatin $(15.05 \pm 0.56 \mathrm{~mm})$. This study also found that the $50 \%$ concentration of the tamarillo fruit decoction was the lowest concentration that still had the potency $(8.19 \pm 0.34 \mathrm{~mm})$ to inhibit the growth of Candida albicans.

The potency of tamarillo decoction used in this study against Candida albicans was categorized as low grade. It is assumed that this low grade potency correlated with the polarity of solution used in this decoction process that was water as non polar solution. It is in accordance with the previous study that the polarity potential of the solution used influences the extract's diffusion process into an SDA medium. Extract by polar solution more easily penetrates the SDA medium, resulting in maximal inhibition of the growth of fungal colonies. ${ }^{19}$ The result of this study also in proper with previous study of methanol and ethanol extract herbal plant such as Gelinggang leaves, Rosella flower against Candida albicans that showed higher inhibition grade than those of tamarillo decoction used in this study. ${ }^{17,18}$

The results of the phytochemical test in this study showed the presence of flavonoids and saponins within the tamarillo fruit decoction. Both flavonoids and saponins are known for their anti-fungal potency. ${ }^{20}$ Low grade inhibition potency of tamarillo decoction in this study might due to less concentration of secondary metabolite compound within the decoction that was needed to inhibit the growth of Candida albicans. 


\section{CONCLUSION}

Tamarillo (Cyphomandra betacea Sendtn.) fruit decoction showed an inhibitory potential against the growth of Candida albicans, starting with a concentration of $50 \%$. The concentration of $50 \%$ was the minimum inhibitory concentration, while the strongest inhibitory concentration was found at $100 \%$. Hence, this natural product might be applied as an adjunctive therapy for oral candidiasis. However, further studied are still needed to confirm this result.

\section{CONFLICT OF INTEREST}

There is no conflict of interest in this study.

\section{REFERENCES}

1. Ermawati N. Identifikasi jamur Candida albicans pada penderita stomatitis dengan menggunakan metode swab mukosa mulut pada siswa SMK Analis Bhakti Wiyata Kediri [Tesis]. Kediri: Fakultas Keguruan dan Ilmu Pendidikan Universitas Nusantara PGRI Kediri. 2013.

2. Amin Z, Uyainah A, Yunihastuti E, Djoerban Z. Profil pasien TB-HIV dan non TB-HIV di RSCM. Buletin Penelitian Kesehatan. 2013;41(4):195-9.

3. Sardi JCO, Scorzoni L, Bernardi, T, Fusco Ameida AM, Mendes G, MJS. Candida species: current epidemiology, pathogenicity biofilm formation, natural antifungal products and new therapeutic options. J Med Microbiol. 2013;62:10-24.

4. Sasongkowati R. Identifikasi Candida sp. Menggunakan primer campuran spesifik dengan teknik PCR multiplex terhadap target DNA topoisomerase II [Tesis]. Surabaya: Universitas Airlangga. 2008.

5. Putri N, Ramatri D, Sugiartati R, Deviyanti S, Abraham S. Uji in vitro anti jamur Candida albicans dari minuman kemasan yoghurt dan kefir. Jakarta: Jurnal Ilmiah dan Teknologi Kedokteran Gigi. 2011;8(1):36-40.

6. Sari ER, Nugraheni ER. Uji aktivitas anti fungi ekstrak etanol daun cabai Jawa (Piper retrofractum) terhadap pertumbuhan Candida albicans. Biofarmasi Jurnal Fakultas Matematika dan Ilmu Pengetahuan Alam Universitas Sebelas Maret. 2013;11(2):36-42.

7. Setiabudy R. Farmakologi dan terapi. Ed 5. Jakarta: Fakultas Kedokteran Universitas Indonesia. 2013. p. 18.

8. Masloman AP, Pangemanan DHC, Anindita PS. Uji daya hambat ekstrak daun sirsak (Annonamurcata L.) terhadap pertumbuhan jamur Candida albicans. Jurnal Ilmiah Farmasi UNSRAT. 2016;5(4):61-8

9. Utami P. Buku pintar tanaman obat. Jakarta: PT Agromedia Pustaka. 2008.
10. Suparmi, Wulandari A. Herbal Nusantara 1001 ramuan tradisional asli Indonesia. Yogyakarta: Andi Offset. 2012.

11. Sembiring LR, Purwijantiningsih LME, Pranata S. Pemanfaatan ekstrak biji terung Belanda (Cymphomandra betacea Sendtn) sebagai pewarna alami es krim. Jurnal Universitas Atma Jaya Yogyakarta. 2013:2(4):41-7.

12. Osorio C, Hurtado N, Dawid C, Hofmann T, Heredia-Mira FJ, Morales AL. Chemical characterisation of anthocyanins in tamarillo (Solanum betaceum Cav.) and Andes berry (Rubus glaucus Benth.) Fruits. Food Chemistry. 2012; 132 (4):1915-21.

13. Filho A, Fernandes H, Pereira de Sousa J, Lemos de Azevedo Maia G, Filho J, Assis T, et al. Antifungal effect of flavonoid 5, 7, 4'-trimethoxyflavone against Candida krusei strains. Int $\mathbf{J}$ Trop Dis Health. 2015;5(2):136-40.

14. Masbintoro A, Agustini SM, Djauhari TNS. Pengaruh ekstrak buah terong Belanda (Solanum betaceum) sebagai anti oksidan terhadap kadar malondialdehida pada tikus putih (Rattus novergicus) yang diinduksi $\mathrm{CCL}_{4}$. Jurnal Universitas Muhammadiyah Malang. 2016;12(1):38-42.

15. Suni NA, Wowor VNS, Leman MA. Uji daya hambat rebusan daun pepaya (Carica papaya) terhadap pertumbuhan Candida albicans pada plat resin akrilik polimerisasi panas. Jurnal e-GiGi (eG). 2017;5(1):77-84.

16. Ningsih DR, Zusfahair, Mantari D. Ekstrak daun mangga (Mangifera indica L.) sebagai anti jamur terhadap jamur Candida albicans dan identifikasi golongan senyawanya. Jurnal Kimia Universitas Jenderal Sudirman. 2017;2(1):61-8.

17. Alioes Y, Kartika A, Zain EA, Azzura V. Uji potensi antijamur Candida albicans ekstrak daun geliggang (Cassia alata L.) dibandingkan dengan sediaan daun sirih yang beredar di pasaran secara in vitro. Jurnal Kimia Riset. 2016;3(2):108-15.

18. Effendy L. Potensi anti jamur kombinasi ekstrak etanol daun sirih merah (Pipercrocatum Ruiz \& Pav.) dan kelopak bunga Rosella (Hibiscus sabdariffa Linn.) terhadap Candida albicans. Jurnal Ilmiah Mahasiswa Universitas Surabaya. 2013;2(1):1-10.

19. Octarya Z, Saputra R. Pengaruh jenis pelarut terhadap jumlah ekstrak dan daya antifungi daun Ketepeng Cina (Cassia alata 1.) terhadap jamur Trychophyton sp. Photon Journal Sain dan Kesehatan. 2015,5(2):15-21.

20. Zhang YS, HY Yi, HF Tang. Cytotoxic sulfated triterpene glycosides from the sea cucumber Pseudocolochirus violaceus. Chem Biodiv. 2006;3(2):807-17. 